\title{
Experiences with prosthetic reconstruction of the trachea and bifurcation
}

\author{
H TOOMES, G MICKISCH, I VOGT-MOYKOPF
}

From the Department of Thoracic Surgery, Rohrbach Hospital, Clinic for Thoracic Medicine, Heildelberg, West Germany

ABSTRACT Extensive tracheal resections were performed to avoid imminent asphyxia in nine patients. Airway continuity was restored with either a straight or a bifurcated Neville prosthesis. One patient had progressive perichondritis and the remaining eight had advanced malignancy. Three patients died of complications due to the prosthesis, 15 days, seven months, and 10 months after operation. Five patients from their underlying disease and one patient is alive 13 months after reconstruction.

For more than 30 years various materials have been used for prosthetic reconstruction of the trachea and bifurcation, in animal studies and subsequently in man (table 1). ${ }^{1-38}$ The frequent changing of materials, combined with the short survival of the patients after reconstruction, reflects the unsolved problem of synthetic substitution. For good prosthetic reconstruction of the trachea there are five essential conditions-namely, airproof sealing, flexibility to avoid erosion of major blood vessels, good tissue tolerance with minimal reaction, resistance to incrustation and bacterial invasion, and the possibil-

Table 1 Materials used for prosthetic tracheal reconstruction with references to published papers

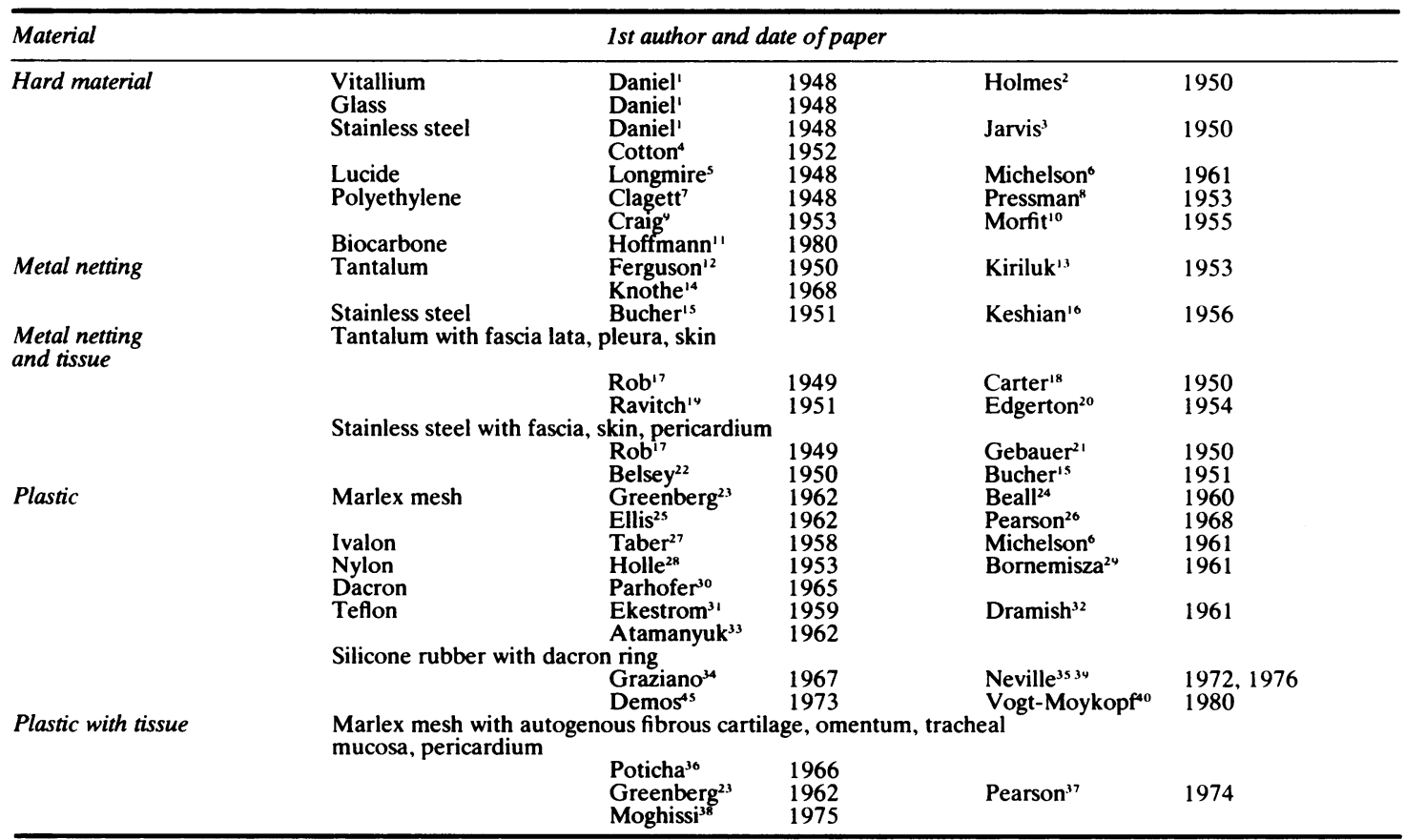

Address for reprint requests: Dr Heikki Toomes, Rohrbach Hospital, Amalienstrasse 5, D-6900 Heildelberg. West Germany.

Accepted 29 August 1984 
ity of epithelialisation.

In practice, most of the materials used do not fulfil these requirements and have to be regarded as of only historical interest. The silicone rubber prosthesis, however described by Neville, ${ }^{34}$ with a nonterminal dacron ring (fig 1 ) and telescopic sinking of the prosthesis into the tracheal lumen is almost ideal except for epithelialisation. It has been of clinical importance since 1967 and experiences with it have been reported during this period. ${ }^{34-41}$

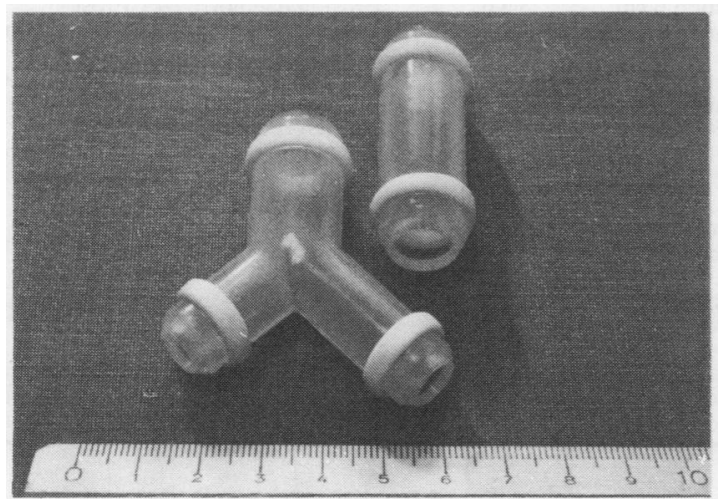

Fig 1 Straight and bifurcated Neville prosthesis (scale in centimetres).

\section{Patients and methods}

Since 1979 we have performed nine resections of the trachea or bifurcation with reconstruction of the airway with a straight or bifurcated Neville prosthesis (figs 2 and 3), using the surgical technique which was originally described. ${ }^{34}$ Eight patients had malignant disease of the trachea and one suffered from progressive perichondritis; clinical details are summarised in table 2 . In three cases $(1,3$, and 5$)$ the approach was through a collar incision, while the remaining six underwent a right thoracotomy. Ventilation was maintained across the operative field in all cases and extracorporeal oxygenation was not required.

All patients were operated on because of extreme dyspnoea and life threatening asphyxia. The decision to use prosthetic reconstruction was made only at operation when it was found impossible to perform end to end anastomosis, because of the length of tracheal resection required.

\section{Case reports}

A 49 year old man was referred with an extensive squamous carcinoma of the middle third of the trachea. When admitted to us he had severe respiratory distress that required immediate endo-

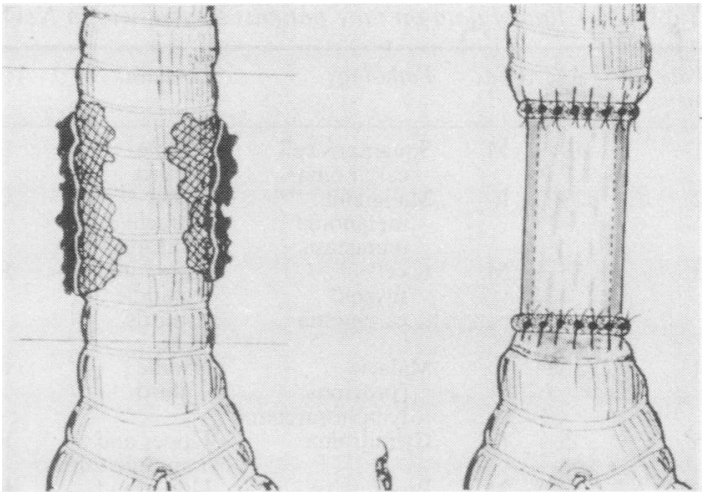

Fig 2 Diagrammatic representation of tracheal replacement showing a straight Neville prosthesis.

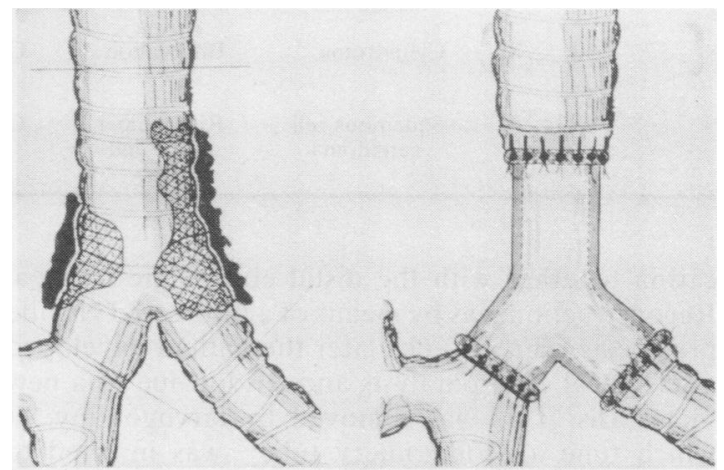

Fig 3 Diagrammatic representation of carinal replacement using a bifurcated Neville prosthesis.

tracheal intubation. Bronchoscopically the tumour was causing a $4 \mathrm{~cm}$ stenosis of the trachea and appeared to be resectable. Operation was performed through a collar incision but it showed that the tumour had invaded the thyroid gland and the connective tissue on both sides of the trachea. A palliative resection of the tumour together with $7 \mathrm{~cm}$ of the trachea was performed with reconstruction using a straight Neville prosthesis. The postoperative course was uncomplicated and three weeks later radiotherapy was commenced. Two months after operation the patient died suddenly with heart failure.

\section{CASE 2}

A 29 year old woman who had had a malignant melanoma removed from the occipital region nine years previously was referred with haemoptysis and dyspnoea. Bronchoscopy showed a mass of tumour in the distal trachea and bifurcation. At operation the extent of the tumour required resection of the 
Table 2 Clinical data on nine patients treated with a Neville prosthesis

\begin{tabular}{|c|c|c|c|c|c|c|c|c|}
\hline $\begin{array}{l}\text { Patient } \\
\text { no }\end{array}$ & Age & Sex & Pathology & Location & Operation & $\begin{array}{l}\text { Survival } \\
\text { time }\end{array}$ & $\begin{array}{l}\text { Complications due } \\
\text { to prosthesis }\end{array}$ & $\begin{array}{l}\text { Cause of } \\
\text { death }\end{array}$ \\
\hline 1 & 49 & $\mathbf{M}$ & $\begin{array}{l}\text { Squamous cell } \\
\text { carcinoma }\end{array}$ & $\begin{array}{l}\text { Middle } \\
\text { third }\end{array}$ & $\begin{array}{l}\text { Resection } 7 \mathrm{~cm} \text {, } \\
\text { straight prosthesis }\end{array}$ & $2 \mathrm{~m}$ & & Tumour \\
\hline 2 & 29 & $\mathbf{F}$ & $\begin{array}{l}\text { Malignant } \\
\text { melanoma } \\
\text { metastasis }\end{array}$ & $\begin{array}{l}\text { Distal } \\
\text { trachea and } \\
\text { bifurcation }\end{array}$ & $\begin{array}{l}\text { Carinal resection, } \\
\text { bifurcated } \\
\text { prosthesis }\end{array}$ & $4 m$ & Sputum retention & Tumour \\
\hline 3 & 55 & $\mathbf{M}$ & $\begin{array}{l}\text { C cell } \\
\text { thyroid } \\
\text { carcinoma }\end{array}$ & $\begin{array}{l}\text { Upper and } \\
\text { middle } \\
\text { thirds }\end{array}$ & $\begin{array}{l}\text { Resection } 9 \mathrm{~cm}, \\
\text { caval patch, } \\
\text { bifurcated } \\
\text { prosthesis }\end{array}$ & $10 \mathrm{~d}$ & & $\begin{array}{l}\text { Cardio- } \\
\text { respiratory } \\
\text { insufficiency }\end{array}$ \\
\hline 4 & 55 & $\mathbf{F}$ & $\begin{array}{l}\text { Malacia } \\
\text { (previous } \\
\text { lymphosarcoma) }\end{array}$ & $\begin{array}{r}\text { Middle } \\
\text { third }\end{array}$ & $\begin{array}{l}\text { Resection } 6 \mathrm{~cm} \\
\text { straight prosthesis }\end{array}$ & $15 \mathrm{~d}$ & Erosion haemorrhage & $\begin{array}{l}\text { Erosion } \\
\text { haemorrhage }\end{array}$ \\
\hline 5 & 55 & $\mathbf{M}$ & Cylindroma & $\begin{array}{l}\text { Upper and } \\
\text { middle thirds }\end{array}$ & $\begin{array}{l}\text { Resection } 8 \mathrm{~cm} \\
\text { straight prosthesis }\end{array}$ & $7 \mathrm{~m}$ & $\begin{array}{l}\text { Loosening of } \\
\text { prosthesis }\end{array}$ & Septicaemia \\
\hline 6 & 54 & $\mathbf{M}$ & $\begin{array}{l}\text { Progressive } \\
\text { perichondritis }\end{array}$ & $\begin{array}{l}\text { Upper and } \\
\text { middle thirds }\end{array}$ & $\begin{array}{l}\text { Resection } 6 \mathrm{~cm} \\
\text { straight prosthesis }\end{array}$ & $10 \mathrm{~m}$ & $\begin{array}{l}\text { Sputum retention, } \\
\text { loosening of } \\
\text { changing of } \\
\text { prosthesis }\end{array}$ & $\begin{array}{l}\text { Erosion } \\
\text { haemorrhage }\end{array}$ \\
\hline 7 & 58 & $\mathbf{M}$ & $\begin{array}{l}\text { Squamous cell } \\
\text { carcinoma }\end{array}$ & $\begin{array}{l}\text { Right main } \\
\text { bronchus and } \\
\text { carina }\end{array}$ & $\begin{array}{l}\text { Pneumonectomy, } \\
\text { carinal resection, } \\
\text { straight prosthesis }\end{array}$ & $4 m$ & & Tumour \\
\hline 8 & 50 & $\mathbf{M}$ & Cylindroma & Bifurcation & $\begin{array}{l}\text { Carinal resection, } \\
\text { bifurcated } \\
\text { prosthesis }\end{array}$ & $13 \mathrm{~m}_{\text {(alive) }}$ & $\begin{array}{l}\text { Granulation tissue, } \\
\text { laser coagulation }\end{array}$ & \\
\hline 9 & 63 & $\mathbf{M}$ & $\begin{array}{l}\text { Squamous cell } \\
\text { carcinoma }\end{array}$ & $\begin{array}{l}\text { Right upper } \\
\text { lobe and } \\
\text { carina }\end{array}$ & $\begin{array}{l}\text { Carinal resection, } \\
\text { bifurcated } \\
\text { prosthesis }\end{array}$ & $8 \mathrm{~d}$ & Sputum retention & $\begin{array}{l}\text { Cardio- } \\
\text { respiratory } \\
\text { insufficiency }\end{array}$ \\
\hline
\end{tabular}

carina together with the distal end of the trachea. Reconstruction was by means of a bifurcated Neville prosthesis. Three weeks later the patient developed a left vocal cord paralysis and stridor due to a new metastasis. This was removed by laryngotomy, at which time a Montgomery tube ${ }^{42}$ was inserted to avoid difficulties with retention of sputum. The patient subsequently learned to conduct suction through the Montgomery tube herself and was discharged. Four months later she died from further dissemination of her tumour.

CASE 3

A 55 year old man had resection of $9 \mathrm{~cm}$ of the trachea through a collar incision, for an extensive thyroid carcinoma with dyspnoea and stridor. In the course of removal of lymph node metastases severe venous bleeding occurred. A right thoracotomy showed that the superior vena cava was invaded by tumour and this was tangentially resected and closed with a patch from the azygos vein. Airway continuity was restored with a straight Neville prosthesis, but the patient did not recover from this procedure and died 10 days later in the intensive care unit.

\section{CASE 4}

A 55 year old woman was admitted with severe respiratory distress two years after radiotherapy to the mediastinum for a lymphosarcoma. Bronchos- copy reveal extensive malacia of the middle third of the trachea. At operation $6 \mathrm{~cm}$ of the trachea had to be resected. Despite extensive mobilisation of the remaining trachea an end to end anastomosis was not possible owing to a loss of flexibility from the previous irradiation. A straight prosthesis was inserted and wrapped in a soft Gore-Tex patch to prevent erosion of the innominate artery. Despite this, however, a fatal haemorrhage occurred on the 15 th postoperative day. At postmortem examination the patch was found to be folded and stiffened, with resulting damage to the artery. Since then we have abandoned this technique.

\section{CASE 5}

A 55 year old man was referred with a cylindroma (fig 4) of the upper trachea. Through a collar incision $5 \mathrm{~cm}$ of the trachea was resected, but frozen sections showed the margins to be affected by tumour and the resection had to be extended to 8 $\mathrm{cm}$. Despite mobilisation end to end anastomosis could not be performed and a straight Neville prosthesis was inserted. The postoperative course was uneventful, and endoscopy after four months showed the prosthesis still in position and in good condition. Seven months after operation the patient was readmitted with an acute mediastinitis and right sided empyema due to detachment of the prosthesis at its distal end. Despite immediate operation and resuture of the prosthesis the patient died from septicaemia. 


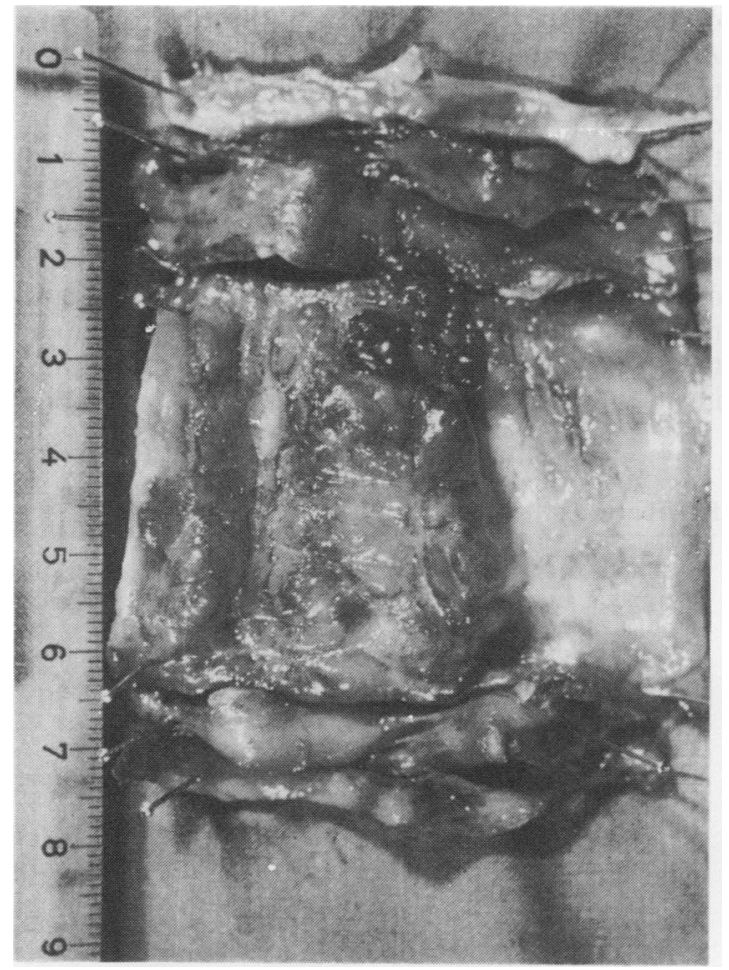

Fig 4 Operative specimen (case 5) showing cylindroma of the trachea with longitudinal extension (scale in centimetres).

\section{(ASt: 6}

A 54 year old man with progressive perichondritis of the upper and middle thirds of the trachea had required a tracheal cannula for some two years. In the past two weeks repeated life threatening cyanutic attacks had occurred despite the use of different types of tracheal tube. Because of severe malacia of the trachea a $6 \mathrm{~cm}$ resection was required but scar tissue, presumably from a mediastinitis, prevented end to end anastomosis and a straight prosthesis was inserted. His postoperative recovery was complicated by sputum retention. Six weeks after operation the prosthesis became loose and partially blocked the tracheal lumen. Reoperation was performed and a new prosthesis inserted (fig 5), combined with a Montgomery tube for sputum control. The patient then made a good recovery and was discharged from hospital after two months. Ten months after operation he died suddenly at home from an erosion haemorrhage.

( A SE: 7

A 58 year old man was referred with respiratory

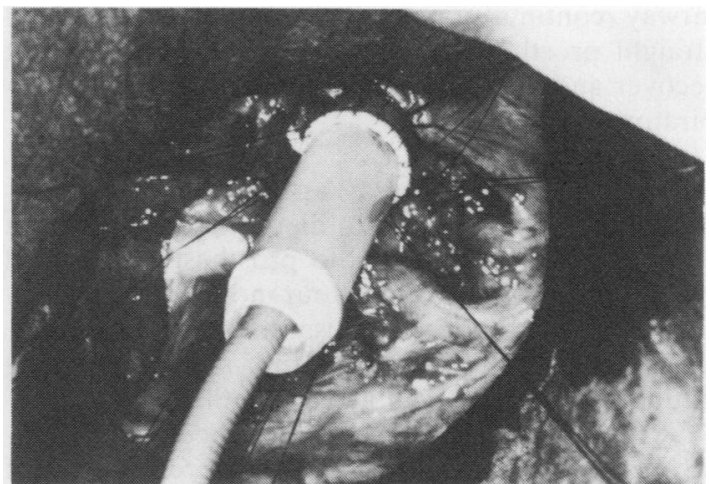

Fig 5 Operative photograph showing insertion of a straight Neville prosthesis over the endotracheal tube.

distress due to a squamous carcinoma of the right main bronchus affecting the carina. Pneumonectomy with resection of the bifurcation of the trachea was performed and the airway reconstructed with a straight prosthesis. Staging showed the tumour to be $\mathrm{T}_{3} \mathrm{~N}_{2} \mathbf{M}_{0}$. The postoperative course was uneventful and the patient was discharged. Four and a half months later he died from recurrence of the tumour with occlusion of the remaining left main bronchus.

CASE 8

A 50 year old man was admitted with atelectasis of the right lower lobe and dyspnoea due to recurrence of a cylindroma of the lower trachea. This had been irradiated nine years previously and for the past four years he had required several endoscopic laser coagulations for tumour recurrence. At bronchoscopy the tumour appeared to be resectable and reconstruction of the bifurcation was planned. His previous irradiation prevented mobilisation of the trachea and a bifurcated prosthesis was inserted. After operation he developed sputum retention but eventually his condition improved and he was discharged after two months. Six and 11 months after operation granulation tissue had to be removed by laser coagulation at the anastomosis with the right main bronchus, but 13 months after operation the prosthesis is in good position and the patient is well.

CASE 9

A 63 year old man was referred with a bronchial carcinoma of the right upper lobe affecting the bifurcation of the trachea. The upper lobe and bifurcation were resected and reconstruction was performed with a bifurcated prosthesis. Three weeks after operation the patient had severe sputum retention and bronchoscopy revealed necrosis of the upper anastomosis. Reoperation was performed, when the right pneumonectomy was completed and 
airway continuity reestablished with two joined straight prostheses. The patient, however, did not recover and died on the eighth day from cardiorespiratory insufficiency.

In this series two patients ( 3 and 9) died after operation and three $(4,5$, and 6$)$ died subsequently from complications related to the prosthesis. One died two months and two others four months after operation from their underlying disease but with the prosthesis functioning satisfactorily. The remaining patient is alive and well at 13 months.

After operation all patients remained in the intensive care unit for at least four days for control of sputum. Bronchoscopic suction was performed as necessary and bronchoscopy was also performed between four and six weeks to assess the state and position of the prostheses. Retention of sputum was an important problem in three patients. In two this was controlled by the insertion of a Montgomery tube while the third recovered with the use of regular mucus solvents.

\section{Discussion}

As a palliative measure severe airway obstruction may be treated by the insertion of different tubes, as described by Montgomery, ${ }^{42}$ Clarke,${ }^{43}$ and Westaby et al. ${ }^{44}$ Definitive treatment, however, requires resection of the obstruction and whenever possible this should be followed by end to end anastomosis of the trachea to restore the continuity of the airway, if necessary with the addition of a laryngeal release. ${ }^{45}$ Prosthetic reconstruction of the trachea should be considered only when anastomosis is not possible, but it may be required if there is extensive scarring which prevents mobilisation (for example, from previous mediastinitis or irradiation), or if an extensive tracheal resection is required.

In 1973 Demos et al $^{46}$ reported on animal experiments with a silicone prosthesis, followed by its use in a single patient with no follow up. In 1976 Neville and Bolanwski reported on 26 patients with reconstruction of the trachea using a silicone rubber prosthesis and dacron sewing ring. ${ }^{39}$ Eight patients had a bifurcated prosthesis and 18 a straight prosthesis. Of the 18 patients with a straight prosthesis, the first 13 did not have the prosthesis telescoped into the lumen and six developed suture granulomas. One death resulted from a complication of the prosthesis with erosion of the innominate artery. Survival of up to five years has been reported.

The problems of granulation tissue and late suture adhesions appear to have been resolved but haemorrhage from erosion of the great vessels can still occur and Neville has recommended protection of the vessels with a double flap of pericardium. Alternative methods which have been suggested for this purpose include the use of the pedicled greater omentum or division of the innominate artery ${ }^{47}$ or the use of de-epithelialised dermal flaps or muscular flaps taken from the sternomastoid muscle. ${ }^{48}$ On the basis of our experience we believe that prosthetic reconstruction does have a place in the management of tracheal obstruction and can give good long term results. Nevertheless the method does have important complications and should be reserved for cases in which direct anastomosis is definitely impossible.

\section{References}

1 Daniel RA jun. The regeneration of defects of the trachea and bronchi: An experimental study. $J$ Thorac Surg 1948; 17:335-49.

2 Holmes CL. In discussion of Gebauer P. Dermal grafts for tracheobronchial reconstruction. J Thorac Surg 1950;20:650.

3 Jarvis FJ. In discussion of Gebauer P. Dermal grafts from tracheobronchial reconstruction. J Thorac Surg 1950;20:649.

4 Cotton BH, Penido JRJ. Resection of the trachea for carcinoma: Report of two cases. J Thorac Surg 1952;24:231-42.

5 Longmire WP jun. Tracheal wounds and injuries, repair of large defects. Ann Otol Rhinol Laryngol 1948;572:875-83.

6 Michelson E, Solomon R, Mann L, Romire J. Experiments in tracheal reconstruction. J Thorac Cardiovasc Surg 1961;41:748-59.

7 Clagget OR, Grindlay JH, Moersch HJ. Resection of the trachea: An experimental study and a report of a case. Arch Surg 1948;57:253-66.

8 Pressman JJ. Experimental tracheal implants. Ann Otol Rhinol Laryngol 1953;62:791-802.

9 Craig RL, Holmes GW, Shabart EJ. Resection and replacement with prosthesis. J Thorac Surg 1953;25:384-96.

10 Morfit HM and others. Sleeve resections (including use of polyethylene tube). Experimental studies on regenerative capacity and principles of reconstruction and repair. Arch Surg 1955;70:654-61.

11 Hoffmann TH, Randell HT. Comparison of lobectomy and wedge resection for carcinoma of the lung. $J$ Thorac Surg 1980;79:211-7.

12 Ferguson DJ, Wild JJ, Wangensteen $\mathrm{OH}$. Experimental resection of the trachea. Surgery 1959;28:597-603.

13 Kiriluk LB, Richer WA jun, Merendino KA. Experimental evaluation in dog of bronchial transplantation, bronchial, tracheal and tracheobronchial resection with reconstruction. Ann Surg 1953;137:490-503.

14 Knothe W. Bronchiektasen und Lungenabszesse. Thoraxchirurgie 1967;15:488-98.

15 Bucher RM, Burnett E, Rosemond GP. Experimental reconstruction of the trachea and bronchial defects with stainless steel wire mesh. J Thorac Surg 1951;21:572-83.

16 Keshishian JM, Blades B, Beattie EJ jun. Tracheal reconstruction. J Thorac Surg 1956;32:707-25. 
17 Rob CG, Bateman GH. Reconstruction of the trachea and cervical esophagus: Preliminary report. Br J Surg 1949;37:202-5.

18 Carter MG, Strieder JW. Resection of trachea and bronchi: Experimental study. J Thorac Surg 1950;20:613-27.

19 Ravitch M. In discussion of Gebauer P. Reconstructive surgery of the trachea and bronchi: late results with dermal grafts. $J$ Thorac Surg 1951;21:568.

20 Edgerton MT, Zorchian A. Reconstruction of the trachea and infraglottic larynx. Plast Reconstr Surg 1954; 13: 167-92.

21 Gebauer PW. Further experiences with dermal grafts for healed stenosis of bronchi and trachea. $J$ Thorac Surg 1950;20:628-47.

22 Belsey $R$. Resection and reconstruction of the intrathoracic trachea. Br J Surg 1950;38:200-5.

23 Greenberg SD, Wilms RK. Tracheal prosthesis: An experimental study in dogs. Arch Otolaryngol 1962;75:335-71.

24 Beall AC jun, Harrington OB, Greenberg SD, Morris GC Jr, Usher FC. Tracheal replacement with heavy Marlex mesh. Arch Surg (Chicago) 1962;87:390-6.

25 Ellis PR, Harrington OB, Beall AC Jr, De Bakey ME. The use of heavy Marlex mesh for tracheal reconstruction following resection for malignancy. $J$ Thorac Cardiovasc Surg 1962;44:520-7.

26 Pearson FG. Henderson RB, Gross AE, Ginsberg RJ, Stone RM. The reconstruction of circumferential tracheal defects with a porous prosthesis. J Thorac Cardiovasc Surg 1968;55:605-16.

27 Taber RE, Tomatis R. Experimental and clinical utilization of prostheses for replacement of the trachea. AMA Arch Surg 1958;77:576-83.

28 Holle F. Healing conditions of tracheobronchial tree and its plastic reconstruction. Experimental study. Arch Klin Chir 1953;277:1-35.

29 Bornemisza G. Experimental substitution of tracheal defects with the aid of auto-alloplastic methods. Bruns Beitr Klin Chir 1961;202:368-76.

30 Parhofer R. Experimentelle Untersuchungen zur Uberbruckung von Tracheadefekten mit Kunststoffprothesen. Thoraxchirurgie 1965;13:17-28.

31 Ekestrom S. Experimental reconstruction of intrathoracic trachea. Acta Chir Scand 1956; 110:367-72.

32 Kramish D, Morfit HM. The use of Teflon prosthesis to bridge complete sleeve defects in the human trachea. Am J Surg 1963; 106:704-8.

33 Atamanyuk MY, Melrose DG. The treatment of cir- cumferential defects of the trachea. $\mathrm{Br} J$ Surg 1962;52:59-62.

34 Graziano JL, Spinazzola A, Neville WE. Prosthetic replacement of the tracheal carina. Ann Thorac Surg 1967; 4: 1-11.

35 Neville WE, Hamouda F, Anderson J, Dwan FM. Replacement of the intrathoracic trachea and both stem bronchi with a molded silatic prosthesis. $J$ Thorac Cardiovasc Surg 1972;63:569-76.

36 Poticha SM, Lewis FJ. Experimental replacement of the trachea.J Thorac Cardiovasc Surg 1966;52:61-7.

37 Pearson FG, Thompson DW, Weissberg D, Simpson WJK, Kergin FG. Adenoid cystic carcinoma of trachea. Experience with 16 patients managed by tracheal resection. Ann Thorac Surg 1974;18:16-29.

38 Moghissi K. Tracheal reconstruction with prosthesis of Marlex mesh and pericardium. J Thorac Cardiovasc Surg 1975;69:499-506.

39 Neville WE, Bolanwski PJP. Prosthetic reconstruction of the trachea and carina. J Thorac Carviovasc Surg 1976;72:525-38.

40 Vogt-Moykopf I, Lullig H, Toomes H, Weidauer $H$. Tracheaersatz am Menschen, kombinierte Eingriffe an Bronchien und Gefaessen der Lunge. Langenbecks Arch Chir 1980; 352:285-9.

41 Weidauer H, Vogt-Moykopf I, Toomes H. Der prothetische Trachealersatz mit Kunststoff. Laryngol Rhinol 1981;6:29-32.

42 Montgomery WW. Silicone tracheal T-tube. Ann Otol Rhinol Laryngol 1974;83:71-5.

43 Clarke DB. Palliative intubation of the trachea and main bronchi. J Thorac Cardiovasc Surg 1980;80:736-41.

44 Westaby SB, Jackson JW, Pearson FG. A bifurcated silicone rubber stent for relief of tracheobronchial obstruction. J Thorac Cardiovasc Surg 1982;83:414-7.

45 Dedo HH, Fishmann NH. Laryngeal release and sleeve resection for tracheal stenosis. Ann Otol Rhinol Laryngol 1969; 78:285-96.

46 Demos NJ, Kutnick H, McCally D, Feinberg F, McKeon J, Timmes JJ. Tracheal regeneration in longterm survivors with silicone prosthesis. Ann Thorac Surg 1973;16:293-300.

47 Grillo HC. Surgical treatment of postintubation tracheal injuries. $J$ Thorac Cardiovasc Surg 1979; 78:860-75.

48 Denecke HJ. Fehler und Gefahren bei der Tracheotomie. Verhand d Deutsch Gesellsch $f$ HNOHeilk Kopf-u-Hals Chirurg XLII Jahresvers Reichenhall 1971:391-402. 